\title{
COVID-19 and the pituitary
}

\author{
Stefano Frara ${ }^{1}$. Agnese Allora ${ }^{1} \cdot$ Laura Castellino $^{1} \cdot$ Luigi di Filippo $^{1} \cdot$ Paola Loli $^{1} \cdot$ Andrea Giustina $^{1} \mathbb{C}$
}

Accepted: 20 April 2021 / Published online: 3 May 2021

(c) The Author(s), under exclusive licence to Springer Science+Business Media, LLC, part of Springer Nature 2021

\begin{abstract}
Background Despite COVID-19 being identified as severe respiratory viral infection, progressively many relevant endocrine manifestations have been reported greatly contributing to the severity of the clinical presentation. Systemic involvement in COVID-19 is due to the ubiquitous expression of angiotensin-converting enzyme 2 (ACE2) receptor, responsible for the entry in the cells of SARS-CoV-2, Several reports in humans and animal models showed a significant ACE2 mRNA expression in hypothalamus and pituitary cells. Moreover, higher mortality and poorer outcomes have been widely described in COVID-19 patients with obesity, diabetes and vertebral fractures, which are all highly prevalent in subjects with pituitary dysfunctions. Aim To review the main endocrine manifestations of COVID-19 with their possible implications for pituitary diseases, the possible direct and indirect involvement of the pituitary gland in COVID-19, the impact of COVID-19 on the management of established pituitary diseases which can be already at increased risk for worse outcomes and on neurosurgical activities as well as vaccination.

Conclusions Our review underlines that there could be a specific involvement of the pituitary gland which fits into a progressively shaping endocrine phenotype of COVID-19. Moreover, the care for pituitary diseases need to continue despite the restrictions due to the emergency. Several pituitary diseases, such as hypopituitarism and Cushing disease, or due to frequent comorbidities such as diabetes may be a risk factor for severe COVID-19 in affected patients.

There is the urgent need to collect in international multicentric efforts data on all these aspects of the pituitary involvement in the pandemic in order to issue evidence driven recommendations for the management of pituitary patients in the persistent COVID-19 emergency.
\end{abstract}

Keywords Pituitary apoplexy $\cdot$ SIADH $\cdot$ Hyponatremia $\cdot$ Acromegaly $\cdot$ Cushing disease $\cdot$ Hypopituitarism $\cdot$ COVID-19

\section{Introduction}

COVID-19 has been initially identified as a severe potentially lethal respiratory infection caused by severe acute respiratory syndrome coronavirus 2 (SARS-CoV-2) but progressively it became evident that many relevant extrapulmonary manifestations greatly contributed to the severity of the syndrome [1]. Despite likely originating in China, infection has rapidly spread to all the Continents with Mediterranean Countries as Italy and Spain being among the mostly affected. Specifically, in the Northern regions of Italy death rate apparently exceeded that reported in Wuhan and in the

Andrea Giustina

giustina.andrea@hsr.it

1 Institute of Endocrine and Metabolic Sciences, San Raffaele Vita-Salute University and IRCC Hospital, Via Olgettina 60, 20132 Milan, Italy rest of the world. In fact, around half of infected citizens and deaths reported in Italy (105.000 as of today, about 4\% of those reported so far in the world) were reported in Lombardy where our Institution is located [2] leading unfortunately to accumulating a large experience on the different aspects of the disease.

The main extrapulmonary features which worsen the outcomes of the disease include vascular/endothelial, cardiac and neurologic manifestations. However, also kidney, hepatic, gastrointestinal, ocular and dermatological signs and symptoms were reported [1]. Pathophysiologically, systemic involvement in COVID-19 is due to the almost ubiquitous expression of angiotensin-converting enzyme 2 (ACE2) receptor, which has been identified as the responsible for the entry in the cells of SARS-CoV-2, with resulting damages at many organ and tissue levels besides the lung [3]. Additionally, altered immune response with the so called cytokine storm may lead to pleiotropic aspects of COVID-19 [4]. 
In this multifacet setting with time it became more and more evident a key role for endocrine diseases. In fact, we among other were the first to report of an "endocrine phenotype" of COVID-19 due to the involvement of multiple endocrine organs and tissues and hormonal substances, the alterations of which may negatively affect patients with COVID-19 [5-8]. The endocrine manifestations of COVID19 which may be often found also in pituitary diseases are diabetes (DM), obesity and vertebral fractures (VFs) [5-9]. Moreover, since in the last months several papers have been published reporting on pituitary consequences of COVID-19 and on the management of pituitary diseases during the pandemic we thought that a critical analysis of all the published material on those topics so far could have been of value for the practicing endocrinologist and clinician.

Aim of our paper will be to shortly review the main endocrine manifestations of COVID-19 with their possible implications for pituitary diseases. Moreover, we will report on the possible direct and indirect involvement of the pituitary gland in COVID-19 and on the impact of COVID-19 on the management of established pituitary diseases which can be already at increased risk of respiratory complication such as acromegaly [10].

\section{Main endocrine manifestations of COVID-19 and their relevance to pituitary conditions}

Among the most frequently reported endocrine and metabolic abnormalities of COVID-19 DM, obesity and VFs have been reported. Despite their potentially variable incidence based on geographical differences (e.g. vitamin D deficiency is more prevalent in Mediterranean than in Scandinavian Countries and this may heavily impact in susceptibility to VFs) [11] all these comorbidities may be relevant to pituitary patients as follows:

\section{Diabetes mellitus (DM)}

DM rapidly emerged as one of the more frequent (prevalence between 7 and 30\% according to different case series) and clinically relevant (with increased risk of hospitalization, severe pulmonary involvement and mortality vs. nondiabetic patients) comorbidities of hospitalized COVID-19 patients [12]. Also, deranged glycemic control negatively affected disease activity and outcomes [13].

Recent studies showed that $\beta$-cells express ACE2 receptor and that SARS-CoV-2 may directly act at the pancreatic level worsening hyperglycemia, ketoacidosis and hyperosmolarity with high-dose insulin requirement in patients with pre-existing DM but also causing newly onset DM in previously non diabetic subjects $[14,15]$.
Interestingly, this bidirectional relationship between DM and COVID-19 [16] may have relevant impact in patients with pituitary diseases. In fact, DM is a frequent complication of acromegaly, not only as a consequence of an insulinresistant state due to GH excess [17]. Development of DM in patients with acromegaly may increase their already elevated cardiovascular morbidity and mortality [18]. Moreover, the presence of COVID-19 induced DM may also impact on disease treatment [19], since somatostatin receptor ligands (SRLs) particularly pasireotide may directly influence glucose metabolism [20, 21]. Therefore, blood glucose levels should be periodically monitored in patients treated with SRLs [22] to reduce and/or avoid hyperglycemic negative known impact on COVID-19 features, especially in those treated with intravenous glucocorticoids, the standard of care during COVID-19 second wave; in this context, treatment with Pegvisomant [23] has been reported to have more favourable effects on glucose homeostasis than SRLs [17] DM is also frequent and early complication of Cushing disease with relevant prognostic and therapeutic implications since DM may often be difficult to control and the SRL pasireotide which may be used to control endogenous hypercortisolism may negatively influence glucose homeostasis [24-26].

\section{Obesity}

Obese patients are at increased risk for complicated COVID19 and related mortality. Moreover, altered body composition with increased visceral adiposity may negatively impact prognosis in subjects with COVID-19 [7, 27].

Particularly severe obesity is among the key predictors for hospitalization in COVID-19 worsened pneumonia with increased need of invasive ventilation and admission in intensive care unit (ICU) [28] as confirmed by a recent meta-analysis including about 45,000 patients [29].

Obesity and altered body composition also characterize several pituitary diseases such as Cushing disease and acromegaly $[17,24,25,30]$. Interestingly, in hypopituitarism particularly with untreated growth hormone $(\mathrm{GH})$ deficiency (GHD) cardiovascular risk is increased due to altered body composition with abnormal lipid profile and increased proinflammatory cytokines and C-reactive protein (CRP) [31].

\section{Vertebral fractures (VFs)}

We recently reported in more than 100 COVID-19 patients highly prevalent (up to $36 \%$ ) thoracic morphometric VFs on lateral chest X-rays [32]. In fact, mortality rate was doubled in fractured vs. not fractured patients and greater in those with severe vs. moderate and mild VFs [32].

Therefore, VFs may represent a sensitive clinical marker of frailty in COVID-19 but also being a predisposing factor 
to negative pulmonary outcome in the disease [32]. In fact, VFs are associated with an increased risk of pneumonia and impaired respiratory function also in patients without previous chronic respiratory diseases [33-35]. Interestingly, patients with a wide range of pituitary diseases were consistently reported in the last two decades to be burdened by a very high prevalence of morphometric VFs [36]. Specifically, prevalent VFs were found in one third to half of patients with acromegaly [37], Cushing disease [38], TSHsecreting adenomas [39] and hypopituitarism [40] equally in both sexes. Moreover, in acromegaly and hypopituitarism an increased incidence of VFs was also reported [41, 42].

\section{Main pituitary manifestations of COVID-19}

\section{Pituitary ACE-2 expression}

Coronavirus entry into host cells is mediated by the viral transmembrane spike (S) glycoprotein binding the metallopeptidase ACE2 [43, 44]. ACE2 has been identified as the functional receptor for infection of SARS-CoV and SARS-CoV-2 mediating viral entry in concert with S glycoprotein priming by the host cell transmembrane serine protease 2 (TMPRSS2) [43, 44]. SARS-CoV-2 revealed a 10-20-fold higher binding affinity as compared to the SARS-CoV explaining at least its higher transmissibility and infectivity [45].

Real-time PCR revealed that ACE2 mRNA expression is present in 72 human tissues, with high expression in cardio-renal tissues but also in ileum, lung, pulmonary blood vessels, brain and prostate [46]. The high expression on lung alveolar epithelial and small intestinal epithelial cells as well as throughout the body confirms the known viral transmission pathways, reflects the main pathogenic involvement of COVID-19 on respiratory and gastrointestinal systems [46] and explains why SARS-CoV-2, once infecting primarily respiratory airways, can spread easily to many other target organs with consequent pleiotropic manifestations [47].

ACE2 expression on cerebral vascular endothelium, neurons and glial cells may play a role in SARS-CoV-2 neural invasion and COVID-19 neurological involvement presenting with headache, confusion, dysgeusia, anosmia, nausea and vomiting $[48,49]$.

ACE2 mRNA expression was reported also in hypothalamus and pituitary gland cells [50]. Moreover, in a previous study, SARS-CoV was detected in pituitary tissues from patients who died from SARS [51].

\section{Pituitary apoplexy}

Pituitary apoplexy is an acute clinical and surgical emergency syndrome due to a sudden hemorrhage and blood infarction of the pituitary gland, typically within a pituitary macroadenoma [52]. Main symptoms referred by patients are sudden onset and severe headache, visual disturbances and ocular palsy due to tumor hemorrhagic and necrotic mass compressing the surrounding optic structures and expanding into the cavernous region [53].

Pituitary apoplexy is usually a rare event (incidence $0.17 / 100,000 /$ year and prevalence $6.2 / 100,000$ ) occurring in $2-12 \%$ of patients with all types of adenoma [53], particularly in those on anticoagulant treatment [54] or in prolactinomas under dopaminergic treatment $[55,56]$.

Previous studies have shown a possible relationship between viral infectious diseases such as the hemorragic fever and direct pituitary vascular damage with ischemic and hemorrhagic signs with foci of necrosis detected in imaging and histological post-mortem evaluations [57, 58]. Moreover, an increased stimulation of the pituitary gland, as occurs in an infectious stress state, may increase pituitary blood demand precipitating acute apoplexy [58].

COVID-19 could be a plausible precipitating risk factor for pituitary apoplexy since SARS-CoV-2 can induce thrombocytopenia, coagulopathy, and platelet dysfunction, having neural tissue tropism due to ACE2 expression in cerebral vascular endothelium [59]. Moreover, the virus has been hypothesized to enter the brain through the nasopharyngeal epithelium via the olfactory nerve, or could pass through the blood-brain barrier or directly reach the median eminence, a circumventricular organ where the blood-brain barrier is lacking [59]. In fact, recently, several cases of pituitary apoplexy associated with COVID-19 mainly in the context of pre-existing macroadenomas were reported (Table 1) [60-65].

Chan et al. reported a case of pituitary apoplexy associated with a third trimester pregnancy complicated by COVID-19 [60]. She presented to urgent care with mild headache, decreased visual acuity in the left eye without diplopia. A cerebral CT scan demonstrated a hemorrhagic mass in the sella suggesting a previously undetected tumor. Moreover, she referred one week of ear pain, body aches, chills and rhinorrhea, and subsequently was tested positive for SARS-CoV-2. Endocrine biochemical work-up only demonstrated low TSH $(0.28 \mathrm{mIU} / \mathrm{L})$, increased serum prolactin $(148.7 \mathrm{ng} / \mathrm{mL})$ and low FSH and $\mathrm{LH}(<0.1$ and $4.6 \mathrm{IU} / \mathrm{L}$, respectively). She was started on dexamethasone $4 \mathrm{mg}$ twice daily. Since the patient was clinically stable, the clinicians decided to undergo vaginal delivery prior to the trans-sphenoidal (TNS) surgery. Two days after delivery she underwent endoscopic TNS surgery. A predominantly liquefied hemorrhagic mass was identified with necrotic 


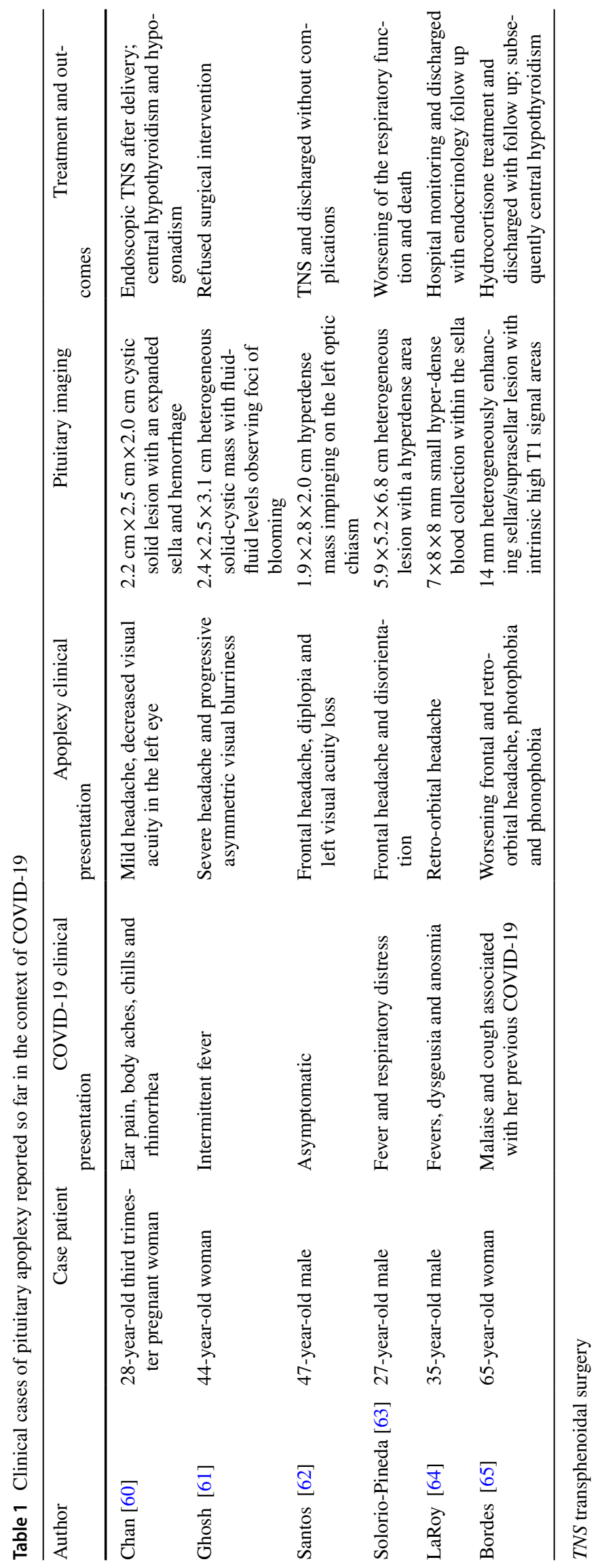


tissue and a markedly expanded sella. Final pathology evaluation demonstrated necrotic tissue without any evidence of viable tumour. Patient follow-up at two months post-op demonstrated central hypothyroidism, and hypogonadism. She remained on levothyroxine $100 \mathrm{mcg}$ and hydrocortisone $10+5 \mathrm{mg}$ daily [60].

Solorio-Pineda et al. reported a case of a 27-year-old male patient hospitalized with drowsiness, respiratory distress, frontal headache, fever and disorientation [63]. A brain CT scan showed a heterogeneous tumoral sellar lesion, with maximal dimensions of $68 \mathrm{~mm}$, and a hyperdense area consistent with hemorrhage. The endocrine biochemical values were all within the normal ranges, except for testosterone. The patient tested positive for SARS-CoV-2 had sudden worsening of the respiratory function, with severe hypoxemia refractory to invasive mechanical ventilation, and died $12 \mathrm{~h}$ after hospital admission [63].

Santos et al. described a 47-year-old male patient who presented to the emergency department (ED) with a left frontal headache that began 5 days before, followed by diplopia, left eye ptosis, and visual loss in left eye [62]. A head CT scan showed a predominantly hyperdense sellar mass $(19 \times 28 \times 20 \mathrm{~mm})$ eccentric to the left with extension into the suprasellar cistern impinging on the left optic chiasm, consistent with pituitary macroadenoma with central hemorrhage. RT-PCR for SARS-CoV-2 was positive one day after his admission. The patient complained of worsening left visual acuity with no improvement of headache and neurosurgeons decided to schedule him for an urgent TNS tumor resection. He was discharged from the hospital four days later without any complication [62].

Ghosh et al. reported a case of a 44-year-old woman admitted to the ED with complaints of a sudden-onset severe headache and progressive asymmetric visual blurriness, symptoms preceded by abrupt-onset intermittent fever [61]. Cognitive and cranial nerve functions were intact except for subtly asymmetric bitemporal hemianopic visual field defects. Patient was tested positive for SARS-CoV-2. Laboratory investigations revealed thrombocytopenia, mild hyponatremia, elevated C-reactive protein and a minimally elevated D-dimer. Contrast-enhanced brain MRI revealed a well-defined large heterogeneous solid-cystic lesion in the suprasellar region $(24 \times 25 \times 31 \mathrm{~mm})$ with fluid-fluid level on gradient-echo images, features suggestive of pituitary macroadenoma with hemorrhage. Low baseline serum cortisol and reduced plasma ACTH levels were found. The patient and her caregivers refused surgical intervention and was kept under follow-up [61].

LaRoy and McGuire reported on a 35-year-old previously healthy male presented to the ED after some days of retroorbital headache, neck stiffness, symptoms of upper respiratory tract infection, fever and anosmia. Oxygen saturation was $95 \%$ with lobular consolidation at chest $\mathrm{x}$-ray and a normal visual and neurologic examination. Head CT showed small hyper-dense lesion within the sella $(7 \times 8 \times 8 \mathrm{~mm})$, not compressing the optic chiasm, and without evidence of other subarachnoid hemorrhage. The patient was tested positive for SARS-CoV-2. Hemorrhagic pituitary microadenoma consistent with pituitary apoplexy was found at MRI. No abnormal hormonal data were found and patient was discharged and kept on follow up [64].

On the other hand, Bordes et al. described a case of pituitary apoplexy attributed solely to COVID-19 in the absence of other identifiable causes and pre-existing pituitary macroadenoma [65].

Based on these evidences, COVID-19-related prothrombotic and endothelial systemic illness may be precipitating risk factors for pituitary apoplexy, especially in patients affected by pituitary adenomas. Therefore, increased awareness toward this complication particularly in predisposed patients (macroadenoma on dopaminergic agents, anticoagulant therapy) is needed not only in specialized pituitary tumor centers [66]. Nevertheless, it can be also thought that due to the reduction in "routine" activities in Neurosurgical departments urgent referrals such as those with pituitary apoplexy may just be among the few patients with pituitary diseases seen during the pandemic.

\section{Hyponatremia-syndrome of inappropriate antidiuretic hormone secretion (SIADH)}

Hyponatremia, defined by serum sodium levels less than 135 $\mathrm{mMol} / \mathrm{L}$, is frequent among patients with COVID-19, who sometimes may present only with symptoms and clinical signs secondary to this electrolytic imbalance.

At the beginning of the pandemic, a number of case reports describing hyponatremia of various etiologies was published [67-70].

Later, a descriptive study of 16 patients hospitalized in the United States for COVID-19 found that 50\% of them had hyponatremia [71], a prevalence similar to that reported in a small Italian study [72]. Results from a large international registry of 4664 hospitalized COVID-19 patients, the Health Outcome Predictive Evaluation for COVID-19 (HOPE) study, found that $20.5 \%$ had hyponatremia at admission. Severe hyponatremia $(<120 \mathrm{mMol} / \mathrm{L})$ was rare occurring in $0.4 \%$ of the patients [73]. Table 2 summarizes the prevalence of hyponatremia in COVID-19 patients reported in available studies.

Hyponatremia at admission was so far independently associated with male sex, old age [73], presence of several comorbidities and diagnosis of severe pneumonia on chest X-ray [74]. Moreover, poorer clinical outcomes and higher 


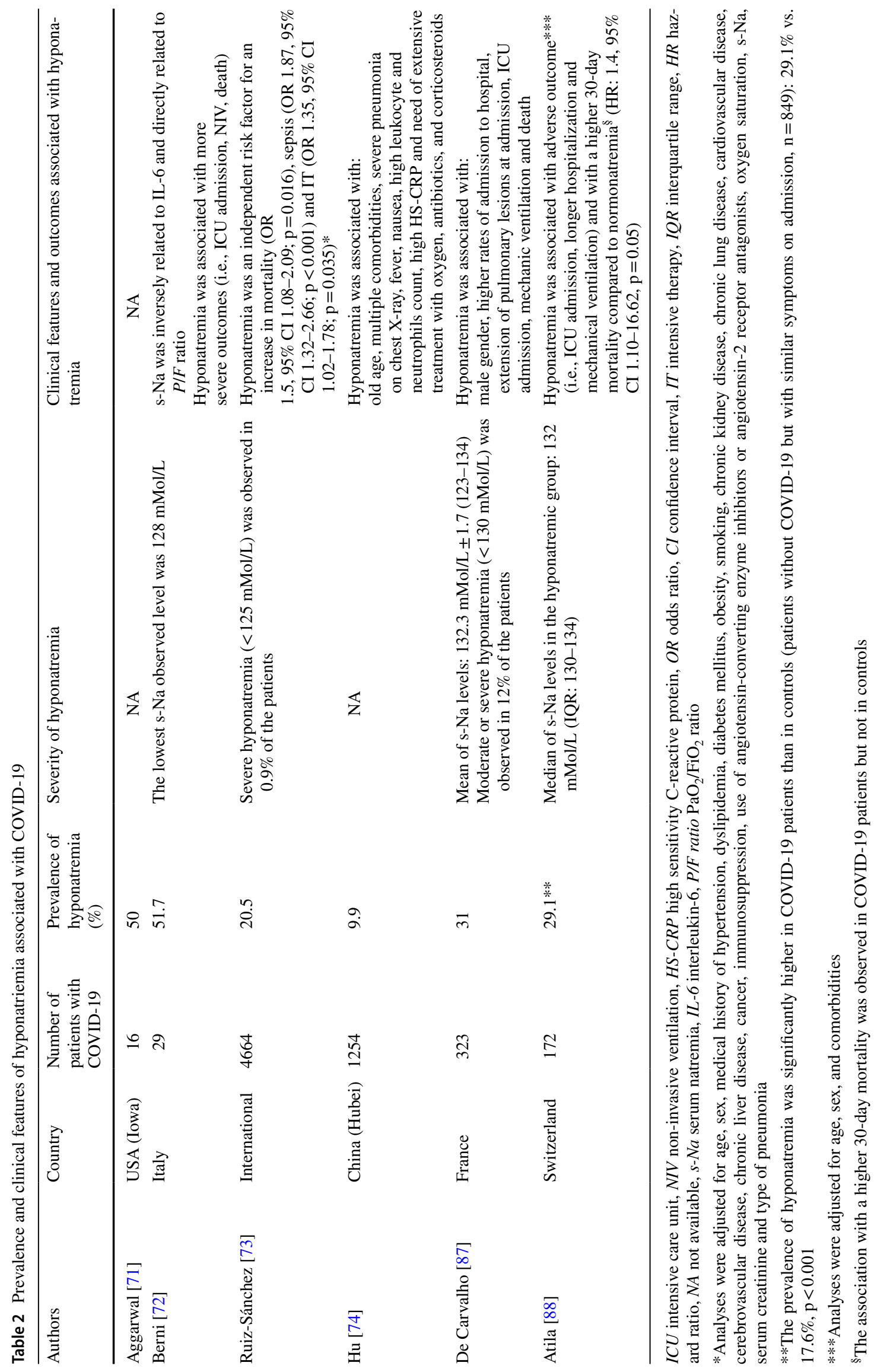


mortality were reported in COVID-19 patients with hyponatremia [75].

The pathophysiological mechanisms proposed to explain hyponatremia among patients with COVID-19 are diverse, including gastrointestinal fluid losses, water depletion, the use of diuretic therapy, urinary sodium loss due to kidney damage and syndrome of inappropriate antidiuretic hormone secretion (SIADH) [74, 76, 77].

SIADH was found in about $40-50 \%$ of patients with hyponatremia in the pre-pandemic era, thus representing the most recognizable cause of this electrolyte disorder; the prevalence was even higher in some pathological conditions such as atypical pneumonia and hyper-inflammation syndrome [78], among main complications of SARS-CoV2 infection [79]. Therefore, it seems reasonable to think that the prevalence of SIADH may be high even in COVID-19 patients.

Currently, a few case reports and a small series of cases with concomitant severe COVID-19 pneumonia were reported [80-84]. Ho et al. reported the first case of COVID-19 associated with SIADH and new-onset seizures [82], whereas Yousaf et al. published a series of three cases of patients diagnosed with COVID-19 with severe acute hyponatremia due to SIADH [80].

However, the exact prevalence of hyponatremia caused by SIADH as well the specific mechanisms behind it in COVID-19 are still unknown.

In this regard, IL-6, the most important cytokine involved in COVID-19, may play a pathogenic role in electrolyte impairment and SIADH by inducing the non-osmotic release of vasopressin [85]. Based on these data, a retrospective Italian study observed in a small cohort of 29 hospitalized COVID-19 patients (15 with hyponatremia upon admission) that tocilizumab, a humanized monoclonal antibody against the IL- 6 receptor, determined a significant increase of sodium levels in $48 \mathrm{~h}$ confirming the hypothesis of an association between IL-6, vasopressin release and sodium itself in COVID-19 patients. Moreover, in the same study, hyponatremia at admission appeared to be inversely related to $\mathrm{IL}-6$ and directly related to $\mathrm{PaO} 2 / \mathrm{FiO} 2$ ratio (an important index of respiratory performance), suggesting that sodium level may be among the criteria for initiating tocilizumab treatment, but also an important predictor of unfavourable outcome [72].

Other causes that can lead to the development of SIADH among patients with COVID-19 may include the use of antibiotics, corticosteroids and positive pressure ventilation (due to non-osmotic stimulation of ADH secretion as pulmonary venous baroreceptors respond to a reduction in effective blood volume) $[74,86]$. Thus, the development of SIADH may be one of the reasons of failure of positive pressure ventilation in COVID-19.
As previously mentioned, an increasing number of studies have showed that hyponatremia may be considered an unfavourable prognostic factor among patients with COVID19. In fact, De Carvalho et al. observed in patients with COVID-19 that hyponatremia at diagnosis was associated with higher rates of hospitalization, ICU admission, use of mechanical ventilation and death, compared to normal sodiemia (34\% vs. $14 \%$ ) [87]. Their results were confirmed by a very recent prospective case-control study in which 172 patients with COVID-19 and 849 controls without COVID19 but similar symptoms were enrolled [88]. In both groups hyponatremia was significantly associated with adverse outcomes such as ICU admission, longer hospitalization, and mechanical ventilation, but importantly 30-day mortality was significantly higher in hyponatremic COVID-19 compared to control group [88].

Finally, also the large HOPE registry reported the role of hyponatremia as an independent risk factor for mortality in patients with COVID-19 [73]. Currently, there are no specific clinical guidelines for the management of hyponatremia in patients diagnosed with COVID-19, with the exception of a recent consensus statement of the Spanish Society for Endocrinology [89]. Although their recommendations are mainly focused on the management during the present pandemic of patients with chronic disorders of water homeostasis, such as diabetes insipidus or chronic hyponatremia, the Authors interestingly underlined the need of hormonal assessment in patients with COVID-19 and newly onset hyponatremia, since COVID-19 may be associated with thyroid dysfunction and adrenal insufficiency both conditions that can lead to hyponatremia.

\section{Hypophysitis}

No data are yet available on possible occurrence of hypophysitis [90] clearly associated with COVID-19, as opposed to what recently reported for the thyroid [91]. In fact, as previously reported, COVID-19 is known to trigger or unleash endocrinopathies both via autoimmune mechanism and through organ damage. Interestingly, a damage in adenohypophyseal functions was observed in some patients during the SARS epidemic in 2003, confirmed by histological changes linked to the severity of the disease in pituitary cells obtained from autopsies [92].

However, since resolution of hypophysitis is usually obtained with administration of glucocorticoids [90], widely used for the treatment of patients with COVID-19, it could be speculated that such therapy may result in a reduced or non-increased incidence of hypophysitis in patients with COVID-19.

Hypophysitis is also a well-known adverse event of anticancer immunotherapy with immune checkpoint inhibitors 
(ICIs) such as the monoclonal antibodies anti-CTLA4, antiPD-1 and anti-PD-L1 [93]. Indeed, these monoclonal antibodies unleash the immune system (mainly T-cells) against tumor cells but can also induce a variety of diverse and distinct immune-related endocrine adverse events [90]. Currently, there are no data showing a change of the incidence of hypophysitis during the present pandemic in patients on therapy with ICIs.

Moreover, since they may directly affect the immune response, concerns have been arisen about the safety of immunotherapies during this pandemic. Indeed, the potential impact of ICIs as well as of other monoclonal antibodies used in endocrine patients such as denosumab [94] on the clinical outcome of COVID-19 has not been yet fully evaluated. However, a very recent case report demonstrated a sufficient cellular and humoral immune response in a SARS-CoV-2 infected patient who was on treatment with immune checkpoint inhibitors for advanced renal cell cancer, supporting the concept of not suspending ICIs during the ongoing COVID-19 pandemic [95].

\section{Pituitary conditions and COVID-19}

\section{Acromegaly}

Acromegaly is a rare but underdiagnosed chronic disease caused by excess GH generally secreted by a pituitary adenoma $[96,97]$ which at presentation is usually a macroadenoma since its diagnosis is often delayed [98]. Acromegaly, if not adequately controlled by multimodal treatment [99], heavily impacts on quality of life and survival due to its several systemic comorbidities affecting cardio-respiratory system, glucose and adipose metabolism and bone health [20].

Since the pandemic was reported to disrupt the usual care of many severe chronic conditions and limit hospital access for affected patients [100] we assessed the effects of COVID19 in acromegaly care through an international online survey [19]. In general, endocrinologist respondents, most of whom were managing a large number of acromegaly patients, reported that COVID-19 emergency caused broad negative effects on the acromegaly care pathway. Marked delays in surgical interventions due to hospital services reorganization with a lack of surgical provision and limited access to pre-surgery COVID-19 testing, especially during first wave emergency were reported [19]. Difficulties in assessing treatment efficacy [101] with neuroradiological follow-up and monitoring of biochemical control as well as importantly of clinical signs and symptoms related to acromegaly and its associated comorbidities [102] were described [19]. In this context, the availability of effective medical therapies [103] often able to control both biochemical and tumoral parameters [104] may by of high value for clinicians particularly when self-administration is possible [103, 105].

The results of this survey also suggested that new approaches necessarily used by pituitary endocrinologists during the COVID-19 emergency such as remote consultations, that reduce the burden of hospital visits, may likely improve acromegaly patient care also in the post-pandemic environment [19].

Finally, although, to date, no clinical cases of SARSCoV-2 complicated infection in acromegaly patients have been reported, several disease-associated comorbidities, as reported above, may negatively influence the course and management of COVID-19 and therefore must be appropriately managed to avoid increased predisposition to viral infection and complications [20]. Among those, particular attention should be given to patients with impaired respiratory function, chronic hypoxemia and hypoventilation caused by the several anatomic and functional modifications typically associated with acromegaly including upper airway obstruction with macroglossia and laryngeal mucosa hypertrophy, kyphoscoliosis with VFs and changes in ribs morphology [10]. Hypertension, probably the most frequent comorbidity associated with severe COVID-19, is also typically found and should be optimally controlled in patients with acromegaly [106].

Pasireotide besides its possible hyperglycemic effects should also be used with caution in patients treated with hydroxychloroquine plus azithromycin, the standard of care during the first wave of the pandemic, since synergistically with these treatments could potentially induce QTc prolongation to which patients with acromegaly may already be predisposed with higher risk of arrhythmias, cardiac complication frequently reported also in COVID-19 patients [1, 96].

In another single-centre, cross-sectional, web-based survey psychosocial status of patients with acromegaly and Cushing disease was compared to that of SARS-CoV-2 infected patients and healthy volunteers [107]. Prevalence of post-traumatic stress disorder was not different in patients with acromegaly vs. Cushing disease vs. healthy controls but higher in SARS-CoV-2 patients; however, frequency of abnormal trait anxiety was significantly higher in patients with acromegaly and SARS-CoV-2 patients vs. those with Cushing disease and healthy controls. Finally, treatment discontinuation rate was higher in acromegaly patients vs. those with Cushing disease [107].

\section{ACTH-dependent and independent Cushing's syndrome}

Susceptibility to infections, hypertension and increased mortality independently of sex and age are specific risk factors 
for some pituitary patients as those affected by Cushing disease [108].

Cardiovascular disease (heart attack and stroke) is the main cause of death, consistent with the increased cardiovascular risk profile that this condition entails [30]. However, the mortality excess is associated also to bacterial, viral and fungal infections, particularly pneumonia, to which patients with hypercortisolism are particularly exposed due to the inhibitory effect of supraphysiological doses of glucocorticoids on the immune system $[108,109]$ such as inhibition of proinflammatory genes [110], stimulation of genes coding for antinflammatory proteins, inhibition of cytokines, direct action on immune system cells $[111,112]$.

Moreover, an increase in venous thromboembolism, as also consistently reported in COVID-19, has been documented in patients with Cushing's syndrome particularly in case of surgical procedures, immobilization, severe infections and cardiovascular events [113]. In fact, patients with autoimmune diseases treated with even moderate doses of glucocorticoids were reported to have 1.5-8 fold increase in thromboembolic risk vs. normal subjects [114].

Based on this background, it was supposed that patients with hypercortisolism could have been prone to severe SARS-CoV-2 infection [115]. Unfortunately, in Cushing disease, at odds with acromegaly, medical treatment is not often effective and well tolerated [116] when surgery is not curative or cannot be easily performed as during the pandemic. In this regard, the block and replace scheme in order to avoid the risk of iatrogenic adrenal insufficiency has been suggested.

Despite these theoretical bases, data from the field on COVID-19 in patients with Cushing disease are still limited. Onset of adrenal failure in a patient with Cushing disease due to a relapsing $\mathrm{ACTH}$-secreting pituitary macroadenoma and COVID-19 pneumonia on treatment with metyrapone and cabergoline was reported. A potential confounding role of enoxaparine used to control the hypercoagulable state in the genesis of persistent hyperkalemia after correction of adrenal insufficiency, due to suppressive effect on aldosterone production was suggested [117].

In a young woman with Cushing disease a moderate to severe COVID-19 was reported despite the lack of known risk factors associated with severe SARS-CoV-2 infection [118]. Recently, in a large Italian series of 61 patients with Cushing disease it has been reported that $3.2 \%$ of them had confirmed COVID-19 as compared to the $0.6 \%$ of the general population. Severe clinical presentation was observed especially in patients with active Cushing disease suggesting that chronic hypercortisolism may be associated with more serious SARS-CoV-2 infection and confirming that patients with biochemically active Cushing disease may be considered a high risk population for COVID-19 [119]. This was recently confirmed in another case series of 22 patients with active Cushing's syndrome, in which three cases of COVID-19 were found ranging from very severe to mild depending on the severity of hypercortisolism [120]. Therefore, strict surveillance and early intervention in suspected SARS-CoV-2 infection in patients with severe hypercortisolism may be recommended.

\section{Hypopituitarism and adrenal insufficiency}

In patients with adrenal insufficiency mortality rate appears to be more than doubled as compared to normal population, mainly due to cardiovascular disease and infections [121], particularly respiratory, which can be serious and expose to increased risk of hospitalization [122] and ICU admission [123] due to altered immune responses with reduced cytotoxic function of NK cells [124]. Clearly, increase in hospital admissions for such patients could also depend on a greater awareness of the risk of adrenal crisis during an infection $[125,126]$.

Importantly, patients with adrenal insufficiency are at high risk of overtreatment since established glucocorticoid replacement regimens do not completely reproduce the endogenous hormonal production and reliable clinical and biochemical markers are lacking [127] with consequent increased risk for DM, overweight, hypertension and chronic inflammatory disease, all conditions currently recognized as risk factors for poor outcomes and death in COVID-19 [7, 8]. However, currently there are still few reports regarding the prevalence and clinical outcomes in patients with hypopituitarism and/or adrenal insufficiency infected and COVID-19.

In a retrospective study with telephone interviews on 279 patients with primary or secondary adrenal insufficiency referring to an Italian tertiary centre [128] no significant differences in prevalence of symptoms suggestive for SARS$\mathrm{CoV}-2$ in patients vs. controls (24 and $22.3 \%$, respectively) were reported without differences between primary and secondary adrenal insufficient subgroups. Nor patients reported adrenal crisis neither required hospitalization [128].

Reasons for the observed longer duration of highly suggestive symptoms along with higher prevalence of gastrointestinal symptoms in controls were suggested to be the more rigorous behaviours adopted by the patients' group due to the detailed instructions in the management of infectious complications routinely received during follow-up. Moreover, it was speculated that cytokine release in the gastrointestinal tract, could have been mitigated in patients by chronic glucocorticoid treatment [128]. Therefore, it could be hypothesized that patients with adrenal insufficiency who are adequately treated and trained do not have higher risk for COVID-19 although since only a few patients had a nasopharyngeal swab these data needs cautious interpretation. 
This observation was previously supported by our group in a brief report on three cases of hospitalized patients with hypopituitarism and documented adrenal insufficiency [129]. In one patient the diagnosis was incidental and the patient remained asymptomatic till the swab returned negative. In the other two cases mild to moderate symptoms were reported and patients were treated with ritonavir/lopinavir and hydroxychloroquine or antibiotic therapy and prophylactic low-molecular-weight heparin. In two of these patients hydrocortisone dose was increased during hospitalization either maintaining the oral administration or switching to the parenteral route. Finally, they were all discharged after 3-6 days, confirming that the severity of the SARS-Cov-2 infection may not be increased in such patients [129].

Noteworthy, recent findings hypothesized possible beneficial effects in severe COVID-19 for both dexamethasone and methylprednisolone [130] likely via inhibition of SARSCoV-2 entry into cells by binding to ACE2 [131]. Use of high dose potent exogenous glucocorticoids may result in suppression of hypothalamic-pituitary-adrenal axis and consequent adrenal insufficiency depending on dose, duration of treatment and individual sensitivity to the drug [128].

Previously, in SARS patients survivors a high prevalence of secondary adrenal insufficiency was reported, the majority of which resolved within a year, suggesting transient hypothalamic-pituitary dysfunction due either to exogenous steroid use or direct viral damage [132].

A further element of concern regarding adrenal hormones and COVID-19 is the use of ritonavir, an antiretroviral drug that markedly inhibits the metabolism of corticosteroids, greatly enhancing their systemic effects with consequent hypercortisolism or, on the contrary, acute hypoadrenalism from pituitary-adrenal suppression at steroid discontinuation [133].

\section{Pituitary surgery and COVID-19}

One of the most clinically relevant consequences of COVID19 pandemic for pituitary patients is the limited access to surgery since being more vulnerable to COVID-19 [134] there is a general risk linked to their hospitalization as well a specific risks resulting from endoscopic endonasal surgery [135] which due to the access via the nasal cavity, paranasal sinuses, or mastoid air cells is considered a high-risk procedure [135]. In fact, TNS pituitary surgery being performed under general anesthesia and requiring intubation and extubation may expose both patients and doctors to the colonized nasal mucosa. Moreover, it usually involves sphenoid drilling which can result in aerosolization of contaminated mucosa of the upper respiratory tract potentially remaining in the air for up to three hours [136]. In fact, increased risk of contagion of surgeons who perform aerosol-generating procedures involving the sinuses was reported [137].

At the beginning of the pandemic period, several regulatory bodies and Specialty Societies recommended to defer elective surgical procedures [138]. As a matter of fact, also in neurosurgical units urgent interventions were prioritized whereas those for benign lesions, as usually are pituitary adenomas [139], were postponed with much longer than usual waiting times or even cancelled [139]. In this context, also among pituitary surgeries prioritization became mandatory. Therefore, the Pituitary Society suggested to stratify pituitary procedures as emerging, urgent or elective. Patients with pituitary apoplexy, severe acute visual loss or other significant mass effects, or suspected for malignant diseases, were considered emerging and had to undergo surgery independently of the current circumstances Patients with pituitary tumor and slowly progressive visual loss, functioning tumors with aggressive features and those with unclear diagnosis, were classified as urgent and in selected cases could undergo surgery. Patients with incidental and asymptomatic tumors, non-functioning adenomas without mass effect or functioning tumors controlled with medical therapy, were classified as elective and the intervention could be postponed [134]. For patients with Cushing disease and acromegaly medical therapy can be first-line treatment, in order to postpone surgery [138].

If surgery cannot be delayed, appropriate recommendations for the management of patients with pituitary tumours should be followed [140]. The initial recommendation for preventive measures were affected by shortage of testing material for SARS-CoV-2 which was recommended only in case of suspected infection [134]. Currently, swab testing appears mandatory for patients before and at the time of hospital entry. Testing for SARS-CoV-2 infection $48 \mathrm{~h}$ before the TNS surgery was proposed, deferring it in case of positive test [141]. Adding a chest CT scan to the nasal swab in high risk of infection surgeries during the pandemic period, was suggested due to the not infrequent false negativity of testing [142-144]. In a patient with COVID-19 that requires emergent surgery, alternative transcranial approaches may be considered, avoiding drilling, and full personal protective equipment for surgeons is recommended [138, 141].

A recent series of 5 patients with resistant acromegaly and Cushing disease submitted to elective endoscopic endonasal surgery during the first wave of the COVID-19 pandemic was recently published [145]. Neurosurgeons reported the following preventive measures: pre-surgical SARS-CoV-2 home testing one week before hospitalization followed by home isolation; in hospital SARS-CoV-2 test on the day before surgery; minimum number of operating team members (two neurosurgeons and nurses and an anaesthesiologist) with maximal protection and minimizing droplet production during intervention with operation room completely 
closed; at the end of the procedure, all "contaminated equipment" eliminated in an ad hoc COVID room. Interestingly, no operator or patient developed COVID-19 symptoms or had positive SARS-CoV-2 swab in the study [145].

Therefore, one year after the beginning of the pandemic pituitary surgery has still to be considered a high risk procedure and when possible can be postponed. However, if all protective measures are carefully followed it can be safely considered, particularly due to the persistent and variable pandemic conditions, in selected patients such as those with acute complications (apoplexy, visual disturbances) and in those who are resistant to medical treatment.

\section{COVID-19 vaccination and pituitary diseases}

Published data on the appropriate effectiveness of the vaccine against COVID-19 have not reported adverse events or particular contraindications in relation to pituitary diseases [146]. The two studies conducted on the mRNA-1273 SARS-CoV-2 and mRNA BNT162b2 Covid-19 vaccine showed no increased prevalence of adverse events or less efficacy of the vaccine in the subpopulation of patients suffering from DM or severe obesity [146, 147] which represent common complications in several patients with pituitary diseases.

The vaccination can give moderate-to-severe systemic side effects such as fever, fatigue, myalgia, arthralgia, and headache [146, 147]. In this regard, the Pituitary Society surveyed its members and recently published a statement on the management of glucocorticoid therapy in patients with adrenal insufficiency who were going to receive the vaccine. Of the 103 respondents, around one third was planning to indicate to their patients to automatically increase the glucocorticoid dose upon vaccination particularly on the day of the vaccine administration but some also prior to the vaccination. The majority of endocrinologists planned to maintain unchanged the glucocorticoid dose in patients with adrenal insufficiency undergoing vaccination with most of them planning to increase glucocorticoid dose only if side effects, prevalently in case of fever but some also for arthralgia and myalgia, were going to occur.

In the absence of specific guidelines or published evidence from the field data from this survey may be of value since they reflect the opinion of clinicians experts in pituitary disease [148]. Finally, it has to be noted that use of systemic i.v. and oral glucocorticoids is among the recommended measures for treatment of rare but already well described severe allergic reaction to COVID-19 vaccines in the general population $[149,150]$.

\section{Conclusions}

COVID-19 pandemic has disrupted every aspect of our life in this last year and represented a huge challenge for doctors, patients and health authorities. In this context our review underlines that there could be a specific involvement of the pituitary gland which fits into a progressively shaping endocrine phenotype of COVID-19. Moreover, it focused on the care for pituitary diseases that are generally benign and chronic but can have acute manifestations which need to be tackled despite the restrictions due to the emergency. Inasmuch, several pituitary diseases per se, such as hypopituitarism and Cushing disease, or due to frequent comorbidities such as DM may represent a risk factor for severe COVID-19 in affected patients.

There is the urgent need to collect in international multicentric efforts data on all these aspects of the pituitary involvement in the pandemic in order to issue evidence driven recommendations for the management of pituitary patients in the persistent COVID-19 emergency.

\section{References}

1. Gupta A, Madhavan MV, Sehgal K, Nair N, Mahajan S, Sehrawat TS, Bikdeli B, Ahluwalia N, Ausiello JC, Wan EY, Freedberg DE, Kirtane AJ, Parikh SA, Maurer MS, Nordvig AS, Accili D, Bathon JM, Mohan S, Bauer KA, Leon MB, Krumholz HM, Uriel N, Mehra MR, Elkind MSV, Stone GW, Schwartz A, Ho DD, Bilezikian JP, Landry DW (2020) Extrapulmonary manifestations of COVID-19. Nat Med 26(7):1017-1032. https://doi.org/ 10.1038/s41591-020-0968-3

2. https://coronavirus.gimbe.org/

3. Lan J, Ge J, Yu J, Shan S, Zhou H, Fan S, Zhang Q, Shi X, Wang Q, Zhang L, Wang X (2020) Structure of the SARS-CoV-2 spike receptor-binding domain bound to the ACE2 receptor. Nature 581(7807):215-220. https://doi.org/10.1038/s41586-020-2180-5

4. Ackermann M, Verleden SE, Kuehnel M, Haverich A, Welte T, Laenger F, Vanstapel A, Werlein C, Stark H, Tzankov A, Li WW, Li VW, Mentzer SJ, Jonigk D (2020) Pulmonary vascular endothelialitis, thrombosis, and angiogenesis in covid-19. N Engl J Med 383(2):120-128. https://doi.org/10.1056/NEJMoa2015432

5. Bilezikian JP, Bikle D, Hewison M, Lazaretti-Castro M, Formenti AM, Gupta A, Madhavan MV, Nair N, Babalyan V, Hutchings N, Napoli N, Accili D, Binkley N, Landry DW, Giustina A (2020) Mechanisms in endocrinology: vitamin D and COVID-19. Eur J Endocrinol 183(5):R133-R147. https://doi.org/10.1530/ EJE-20-0665

6. Brandi ML, Giustina A (2020) Sexual Dimorphism of coronavirus 19 morbidity and lethality. Trends Endocrinol Metab 31(12):918-927. https://doi.org/10.1016/j.tem.2020.09.003

7. Marazuela M, Giustina A, Puig-Domingo M (2020) Endocrine and metabolic aspects of the COVID-19 pandemic. Rev Endocr Metab Disord 21(4):495-507. https://doi.org/10.1007/ s11154-020-09569-2

8. Puig-Domingo M, Marazuela M, Giustina A (2020) COVID-19 and endocrine diseases. A statement from the European Society of Endocrinology. Endocrine 68(1):2-5. https://doi.org/10.1007/ s12020-020-02294-5 
9. Giustina A, Formenti A (2020) Re: Preventing a covid-19 pandemic Can high prevalence of severe hypovitaminosis D play a role in the high impact of Covid infection in Italy? BMJ 368:m810. https://doi.org/10.1136/bmj.m810

10. Zhang F, Guo X, Gao L, Wang Z, Feng C, Jia M, Xing B (2020) Lung function and blood gas abnormalities in patients with acromegaly. J Clin Neurosci 73:130-135. https://doi.org/10.1016/j. jocn.2020.01.003

11. Giustina A, Adler RA, Binkley N, Bollerslev J, Bouillon R, Dawson-Hughes B, Ebeling PR, Feldman D, Formenti AM, LazarettiCastro M, Marcocci C, Rizzoli R, Sempos CT, Bilezikian JP (2020) Consensus statement from 2(nd) international conference on controversies in Vitamin D. Rev Endocr Metab Disord 21 (1):89-116. https://doi.org/10.1007/s11154-019-09532-w

12. Lima-Martinez MM, Carrera Boada C, Madera-Silva MD, Marin W, Contreras M (2020) COVID-19 and diabetes: a bidirectional relationship. Clin Investig Arterioscler. https://doi.org/10.1016/j. arteri.2020.10.001

13. Coppelli A, Giannarelli R, Aragona M, Penno G, Falcone M, Tiseo G, Ghiadoni L, Barbieri G, Monzani F, Virdis A, Menichetti F, Del Prato S, Pisa C-SG (2020) Hyperglycemia at hospital admission is associated with severity of the prognosis in patients hospitalized for COVID-19: the Pisa COVID-19 study. Diabetes Care 43(10):2345-2348. https://doi.org/10.2337/ dc20-1380

14. Cariou B, Hadjadj S, Wargny M, Pichelin M, Al-Salameh A, Allix I, Amadou C, Arnault G, Baudoux F, Bauduceau B, Borot $\mathrm{S}$, Bourgeon-Ghittori M, Bourron O, Boutoille D, CazenaveRoblot F, Chaumeil C, Cosson E, Coudol S, Darmon P, Disse E, Ducet-Boiffard A, Gaborit B, Joubert M, Kerlan V, Laviolle B, Marchand L, Meyer L, Potier L, Prevost G, Riveline JP, Robert R, Saulnier PJ, Sultan A, Thebaut JF, Thivolet C, Tramunt B, Vatier C, Roussel R, Gautier JF, Gourdy P, CORONADO investigators (2020) Phenotypic characteristics and prognosis of inpatients with COVID-19 and diabetes: the CORONADO study. Diabetologia 63(8):1500-1515. https://doi.org/10.1007/ s00125-020-05180-x

15. Apicella M, Campopiano MC, Mantuano M, Mazoni L, Coppelli A, Del Prato S (2020) COVID-19 in people with diabetes: understanding the reasons for worse outcomes. Lancet Diabetes Endocrinol 8(9):782-792. https://doi.org/10.1016/S22138587(20)30238-2

16. Rubino F, Amiel SA, Zimmet P, Alberti G, Bornstein S, Eckel RH, Mingrone G, Boehm B, Cooper ME, Chai Z, Del Prato S, Ji L, Hopkins D, Herman WH, Khunti K, Mbanya JC, Renard E (2020) New-onset diabetes in Covid-19. N Engl J Med 383(8):789-790. https://doi.org/10.1056/NEJMc2018688

17. Frara S, Maffezzoni F, Mazziotti G, Giustina A (2016) Current and Emerging Aspects of Diabetes Mellitus in Acromegaly. Trends Endocrinol Metab 27(7):470-483. https://doi.org/10. 1016/j.tem.2016.04.014

18. Fleseriu M, Biller BMK, Freda PU, Gadelha MR, Giustina A, Katznelson L, Molitch ME, Samson SL, Strasburger CJ, van der Lely AJ, Melmed S (2021) A Pituitary Society update to acromegaly management guidelines. Pituitary 24(1):1-13. https://doi. org/10.1007/s11102-020-01091-7

19. Giustina A, Legg E, Cesana BM, Frara S, Mortini P, Fleseriu M (2021) Results from ACROCOVID: an international survey on the care of acromegaly during the COVID-19 era. Endocrine 71(2):273-280. https://doi.org/10.1007/s12020-020-02565-1

20. Giustina A, Barkan A, Beckers A, Biermasz N, Biller BMK, Boguszewski C, Bolanowski M, Bonert V, Bronstein MD, Casanueva FF, Clemmons D, Colao A, Ferone D, Fleseriu M, Frara S, Gadelha MR, Ghigo E, Gurnell M, Heaney AP, Ho K, Ioachimescu A, Katznelson L, Kelestimur F, Kopchick J, Krsek M,
Lamberts S, Losa M, Luger A, Maffei P, Marazuela M, Mazziotti G, Mercado M, Mortini P, Neggers S, Pereira AM, Petersenn S, Puig-Domingo M, Salvatori R, Shimon I, Strasburger C, Tsagarakis S, van der Lely AJ, Wass J, Zatelli MC, Melmed S (2020) A Consensus on the Diagnosis and Treatment of Acromegaly Comorbidities: An Update. J Clin Endocrinol Metab 105 (4). https://doi.org/10.1210/clinem/dgz096

21. Giustina A, Barkhoudarian G, Beckers A, Ben-Shlomo A, Biermasz N, Biller B, Boguszewski C, Bolanowski M, Bollerslev J, Bonert V, Bronstein MD, Buchfelder M, Casanueva F, Chanson P, Clemmons D, Fleseriu M, Formenti AM, Freda P, Gadelha M, Geer E, Gurnell M, Heaney AP, Ho KKY, Ioachimescu AG, Lamberts S, Laws E, Losa M, Maffei P, Mamelak A, Mercado M, Molitch M, Mortini P, Pereira AM, Petersenn S, Post K, PuigDomingo M, Salvatori R, Samson SL, Shimon I, Strasburger C, Swearingen B, Trainer P, Vance ML, Wass J, Wierman ME, Yuen KCJ, Zatelli MC, Melmed S (2020) Multidisciplinary management of acromegaly: A consensus. Rev Endocr Metab Disord 21(4):667-678. https://doi.org/10.1007/s11154-020-09588-z

22. Mazziotti G, Floriani I, Bonadonna S, Torri V, Chanson P, Giustina A (2009) Effects of somatostatin analogs on glucose homeostasis: a metaanalysis of acromegaly studies. J Clin Endocrinol Metab 94(5):1500-1508. https://doi.org/10.1210/jc.2008-2332

23. Giustina A, Arnaldi G, Bogazzi F, Cannavo S, Colao A, De Marinis L, De Menis E, Degli Uberti E, Giorgino F, Grottoli S, Lania AG, Maffei P, Pivonello R, Ghigo E (2017) Pegvisomant in acromegaly: an update. J Endocrinol Invest 40(6):577-589. https://doi.org/10.1007/s40618-017-0614-1

24. Mazziotti G, Gazzaruso C, Giustina A (2011) Diabetes in Cushing syndrome: basic and clinical aspects. Trends Endocrinol Metab 22(12):499-506. https://doi.org/10.1016/j.tem.2011.09. 001

25. Mazziotti G, Formenti AM, Frara S, Maffezzoni F, Doga M, Giustina A (2017) Diabetes in Cushing disease. Curr Diab Rep 17(5):32. https://doi.org/10.1007/s11892-017-0860-9

26. Scaroni C, Zilio M, Foti M, Boscaro M (2017) Glucose metabolism abnormalities in cushing syndrome: from molecular basis to clinical management. Endocr Rev 38(3):189-219. https://doi. org/10.1210/er.2016-1105

27. Favre G, Legueult K, Pradier C, Raffaelli C, Ichai C, Iannelli A, Redheuil A, Lucidarme O, Esnault V (2021) Visceral fat is associated to the severity of COVID-19. Metabolism 115:154440. https://doi.org/10.1016/j.metabol.2020.154440

28. Simonnet A, Chetboun M, Poissy J, Raverdy V, Noulette J, Duhamel A, Labreuche J, Mathieu D, Pattou F, Jourdain M, LICORN and the Lille COVID-19 and Obesity study group (2020) High prevalence of obesity in severe acute respiratory syndrome coronavirus-2 (SARS-CoV-2) requiring invasive mechanical ventilation. Obesity (Silver Spring) 28(7):11951199. https://doi.org/10.1002/oby.22831

29. Huang Y, Lu Y, Huang YM, Wang M, Ling W, Sui Y, Zhao HL (2020) Obesity in patients with COVID-19: a systematic review and meta-analysis. Metabolism 113:154378. https://doi.org/10. 1016/j.metabol.2020.154378

30. Nieman LK (2019) Hypertension and cardiovascular mortality in patients with cushing syndrome. Endocrinol Metab Clin N Am 48(4):717-725. https://doi.org/10.1016/j.ecl.2019.08.005

31. Gazzaruso C, Gola M, Karamouzis I, Giubbini R, Giustina A (2014) Cardiovascular risk in adult patients with growth hormone $(\mathrm{GH})$ deficiency and following substitution with $\mathrm{GH}-$ an update. J Clin Endocrinol Metab 99(1):18-29. https://doi.org/10. 1210/jc.2013-2394

32. di Filippo L, Formenti AM, Doga M, Pedone E, Rovere-Querini P, Giustina A (2021) Radiological thoracic vertebral fractures are highly prevalent in COVID-19 and predict disease outcomes. 
J Clin Endocrinol Metab 106(2):e602-e614. https://doi.org/10. 1210/clinem/dgaa738

33. Watanabe R, Shiraki M, Saito M, Okazaki R, Inoue D (2018) Restrictive pulmonary dysfunction is associated with vertebral fractures and bone loss in elderly postmenopausal women. Osteoporos Int 29(3):625-633. https://doi.org/10.1007/ s00198-017-4337-0

34. Krege JH, Kendler D, Krohn K, Genant H, Alam J, Berclaz PY, Coffey B, Loghin C (2015) Relationship between vertebral fracture burden, height loss, and pulmonary function in postmenopausal women with osteoporosis. J Clin Densitom 18(4):506511. https://doi.org/10.1016/j.jocd.2015.02.004

35. Kim B, Kim J, Jo YH, Kang SH, Lee YJ, Lee JH, Hwang JE, Park MJ, Lee S (2018) Risk of pneumonia after vertebral compression fracture in women with low bone density: a population-based study. Spine (Phila Pa 1976) 43(14):E830-E835. https://doi.org/ 10.1097/BRS.0000000000002536

36. Mazziotti G, Frara S, Giustina A (2018) Pituitary diseases and bone. Endocr Rev 39(4):440-488. https://doi.org/10.1210/er. 2018-00005

37. Giustina A (2020) Acromegaly and vertebral fractures: facts and questions. Trends Endocrinol Metab 31(4):274-275. https://doi. org/10.1016/j.tem.2020.01.011

38. Frara S, Allora A, Di Filippo L, Formenti A, Loli P, Polizzi E, Tradati D, Ulivieri FM, Giustina A (2021) Osteopathy in mild adrenal Cushing's syndrome and Cushing disease. Best Pract Res Clin Endocrinol Metab. https://doi.org/10.1016/j.beem.2021. 101515

39. Frara S, Losa M, Doga M, Formenti AM, Mortini P, Mazziotti G, Giustina A (2018) High Prevalence of Radiological Vertebral Fractures in Patients With TSH-Secreting Pituitary Adenoma. J Endocr Soc 2(9):1089-1099. https://doi.org/10.1210/js. 2018-00091

40. Mormando M, Chiloiro S, Bianchi A, Giampietro A, Angelini F, Tartaglione L, Nasto L, Milardi D, Formenti AM, Giustina A, De Marinis L (2016) Growth hormone receptor isoforms and fracture risk in adult-onset growth hormone-deficient patients. Clin Endocrinol (Oxf) 85(5):717-724. https://doi.org/10.1111/ cen.13161

41. Mazziotti G, Bianchi A, Porcelli T, Mormando M, Maffezzoni F, Cristiano A, Giampietro A, De Marinis L, Giustina A (2013) Vertebral fractures in patients with acromegaly: a 3-year prospective study. J Clin Endocrinol Metab 98(8):3402-3410. https://doi. org/10.1210/jc.2013-1460

42. Mazziotti G, Doga M, Frara S, Maffezzoni F, Porcelli T, Cerri L, Maroldi R, Giustina A (2016) Incidence of morphometric vertebral fractures in adult patients with growth hormone deficiency. Endocrine 52(1):103-110. https://doi.org/10.1007/ s12020-015-0738-z

43. Li W, Moore MJ, Vasilieva N, Sui J, Wong SK, Berne MA, Somasundaran M, Sullivan JL, Luzuriaga K, Greenough TC, Choe H, Farzan M (2003) Angiotensin-converting enzyme 2 is a functional receptor for the SARS coronavirus. Nature 426(6965):450-454. https://doi.org/10.1038/nature02145

44. Walls AC, Park YJ, Tortorici MA, Wall A, McGuire AT, Veesler D (2020) Structure, Function, and Antigenicity of the SARSCoV-2 Spike Glycoprotein. Cell 183(6):1735. https://doi.org/10. 1016/j.cell.2020.11.032

45. Hoffmann M, Kleine-Weber H, Schroeder S, Kruger N, Herrler T, Erichsen S, Schiergens TS, Herrler G, Wu NH, Nitsche A, Muller MA, Drosten C, Pohlmann S (2020) SARS-CoV-2 Cell Entry Depends on ACE2 and TMPRSS2 and Is Blocked by a Clinically Proven Protease Inhibitor. Cell 181(2):271-280 e278. https://doi.org/10.1016/j.cell.2020.02.052
46. Hamming I, Timens W, Bulthuis ML, Lely AT, Navis G, van Goor H (2004) Tissue distribution of ACE2 protein, the functional receptor for SARS coronavirus. A first step in understanding SARS pathogenesis. J Pathol 203(2):631-637. https://doi. org/10.1002/path.1570

47. Chen N, Zhou M, Dong X, Qu J, Gong F, Han Y, Qiu Y, Wang J, Liu Y, Wei Y, Xia J, Yu T, Zhang X, Zhang L (2020) Epidemiological and clinical characteristics of 99 cases of 2019 novel coronavirus pneumonia in Wuhan, China: a descriptive study. Lancet 395(10223):507-513. https://doi.org/10.1016/S01406736(20)30211-7

48. Mao L, Jin H, Wang M, Hu Y, Chen S, He Q, Chang J, Hong C, Zhou Y, Wang D, Miao X, Li Y, Hu B (2020) Neurologic manifestations of hospitalized patients with coronavirus disease 2019 in Wuhan, China. JAMA Neurol 77(6):683-690. https://doi.org/ 10.1001/jamaneurol.2020.1127

49. Conde Cardona G, Quintana Pajaro LD, Quintero Marzola ID, Ramos Villegas Y, Moscote Salazar LR (2020) Neurotropism of SARS-CoV 2: mechanisms and manifestations. J Neurol Sci 412:116824. https://doi.org/10.1016/j.jns.2020.116824

50. Han T, Kang J, Li G, Ge J, Gu J (2020) Analysis of 2019-nCoV receptor ACE2 expression in different tissues and its significance study. Ann Transl Med 8(17):1077. https://doi.org/10.21037/ atm-20-4281

51. Ding Y, He L, Zhang Q, Huang Z, Che X, Hou J, Wang H, Shen H, Qiu L, Li Z, Geng J, Cai J, Han H, Li X, Kang W, Weng D, Liang P, Jiang S (2004) Organ distribution of severe acute respiratory syndrome (SARS) associated coronavirus (SARS$\mathrm{CoV}$ ) in SARS patients: implications for pathogenesis and virus transmission pathways. J Pathol 203(2):622-630. https://doi.org/ 10.1002/path. 1560

52. Briet C, Salenave S, Bonneville JF, Laws ER, Chanson P (2015) Pituitary apoplexy. Endocr Rev 36(6):622-645. https://doi.org/ 10.1210/er.2015-1042

53. Barkhoudarian G, Kelly DF (2019) Pituitary apoplexy. Neurosurg Clin N Am 30(4):457-463. https://doi.org/10.1016/j.nec.2019. 06.001

54. Doglietto F, Costi E, Villaret AB, Mardighian D, Fontanella MM, Giustina A (2016) New oral anticoagulants and pituitary apoplexy. Pituitary 19(2):232-234. https://doi.org/10.1007/ s11102-014-0616-3

55. Casanueva FF, Molitch ME, Schlechte JA, Abs R, Bonert V, Bronstein MD, Brue T, Cappabianca P, Colao A, Fahlbusch R, Fideleff H, Hadani M, Kelly P, Kleinberg D, Laws E, Marek J, Scanlon M, Sobrinho LG, Wass JA, Giustina A (2006) Guidelines of the Pituitary Society for the diagnosis and management of prolactinomas. Clin Endocrinol (Oxf) 65(2):265-273. https:// doi.org/10.1111/j.1365-2265.2006.02562.x

56. Mancini T, Casanueva FF, Giustina A (2008) Hyperprolactinemia and prolactinomas. Endocrinol Metab Clin N Am 37(1):67-99, viii. https://doi.org/10.1016/j.ecl.2007.10.013

57. Bhoelan S, Langerak T, Noack D, van Schinkel L, van Nood E, van Gorp ECM, Rockx B, Goeijenbier M (2019) Hypopituitarism after orthohantavirus infection: what is currently known? Viruses. https://doi.org/10.3390/v11040340

58. Tan SK, Seow CJ, Tan E, Chau YP, Dalan R (2014) Pituitary apoplexy secondary to thrombocytopenia due to dengue hemorrhagic fever: a case report and review of the literature. Endocr Pract 20(4):e58-e64. https://doi.org/10.4158/EP13319.CR

59. Chigr F, Merzouki M, Najimi M (2020) Autonomic brain centers and pathophysiology of COVID-19. ACS Chem Neurosci 11(11):1520-1522. https://doi.org/10.1021/acschemneuro.0c002 65

60. Chan JL, Gregory KD, Smithson SS, Naqvi M, Mamelak AN (2020) Pituitary apoplexy associated with acute COVID-19 
infection and pregnancy. Pituitary 23(6):716-720. https://doi. org/10.1007/s11102-020-01080-w

61. Ghosh R, Roy D, Roy D, Mandal A, Dutta A, Naga D, BenitoLeon J (2021) A rare case of SARS-CoV-2 infection associated with pituitary apoplexy without comorbidities. J Endocr Soc 5(3):bvaa203. https://doi.org/10.1210/jendso/bvaa203

62. Santos C, Filho L, Santos CAT, Neill JS, Vale HF, Kurnutala LN (2020) Pituitary tumor resection in a patient with SARS-CoV-2 (COVID-19) infection. A case report and suggested airway management guidelines. Braz J Anesthesiol 70(2):165-170. https:// doi.org/10.1016/j.bjane.2020.05.003

63. Solorio-Pineda S, Almendarez-Sanchez CA, Tafur-Grandett AA, Ramos-Martinez GA, Huato-Reyes R, Ruiz-Flores MI, Sosa-Najera A (2020) Pituitary macroadenoma apoplexy in a severe acute respiratory syndrome-coronavirus-2-positive testing: causal or casual? Surg Neurol Int 11:304. https://doi.org/ 10.25259/SNI_305_2020

64. LaRoy M, McGuire M (2021) Pituitary apoplexy in the setting of COVID-19 infection: A case report. Am J Emerg Med. https:// doi.org/10.1016/j.ajem.2021.02.045

65. Bordes SJ, Phang-Lyn S, Najera E, Borghei-Razavi H, Adada B (2021) Pituitary apoplexy attributed to COVID-19 infection in the absence of an underlying macroadenoma or other identifiable cause. Cureus 13(2):e13315. https://doi.org/10.7759/cureus. 13315

66. Frara S, Rodriguez-Carnero G, Formenti AM, Martinez-Olmos MA, Giustina A, Casanueva FF (2020) Pituitary tumors centers of excellence. Endocrinol Metab Clin N Am 49(3):553-564. https://doi.org/10.1016/j.ecl.2020.05.010

67. De La Flor Merino JC, Mola Reyes L, Linares Gravalos T, Roel Conde A, Del RodelesPozo M (2020) An unusual case of severe acute hyponatremia in patient with COVID-19 infection. Nefrologia 40(3):356-358. https://doi.org/10.1016/j.nefro.2020.05.001

68. Tee LY, Yap B, Sidhu GK, Goh KS, Rosario BH (2020) Atypical presentation of COVID-19 in an older adult: lethargy and vomiting from severe hypovolemic hyponatremia. Geriatr Gerontol Int 20(9):839-840. https://doi.org/10.1111/ggi.13990

69. Khan AA, Ata F, Munir W, Yousaf Z (2020) Fluid replacement versus fluid restriction in COVID-19 associated hyponatremia. Cureus 12(7):e9059. https://doi.org/10.7759/cureus.9059

70. Mansoor E, Khoudari G, Abou Saleh M, Elfadawy N, Cooper GS, Katz J, Faulx A (2020) The many faces of COVID-19: atypical presentation of COVID-19 in a patient with Crohn's Disease with acute diarrhea leading to severe hypovolemic hyponatremia - a case report. Am J Gastroenterol 115(10):1730-1731. https://doi.org/10.14309/ajg.0000000000000814

71. Aggarwal S, Garcia-Telles N, Aggarwal G, Lavie C, Lippi G, Henry BM (2020) Clinical features, laboratory characteristics, and outcomes of patients hospitalized with coronavirus disease 2019 (COVID-19): early report from the United States. Diagnosis (Berl) 7(2):91-96. https://doi.org/10.1515/dx-2020-0046

72. Berni A, Malandrino D, Parenti G, Maggi M, Poggesi L, Peri A (2020) Hyponatremia, IL-6, and SARS-CoV-2 (COVID-19) infection: may all fit together? J Endocrinol Invest 43(8):11371139. https://doi.org/10.1007/s40618-020-01301-w

73. Ruiz-Sanchez JG, Nunez-Gil IJ, Cuesta M, Rubio MA, MarounEid C, Arroyo-Espliguero R, Romero R, Becerra-Munoz VM, Uribarri A, Feltes G, Trabattoni D, Molina M, Garcia Aguado M, Pepe M, Cerrato E, Alfonso E, Castro Mejia AF, Roubin SR, Buzon L, Bondia E, Marin F, Lopez Pais J, Abumayyaleh M, D'Ascenzo F, Rondano E, Huang J, Fernandez-Perez C, Macaya C, de Miguel Novoa P, Calle-Pascual AL, Estrada Perez V, Runkle I, investigators HC- (2020) Prognostic impact of hyponatremia and hypernatremia in COVID-19 pneumonia. A HOPE-COVID-19 (Health Outcome Predictive Evaluation for COVID-19) registry analysis. Front Endocrinol (Lausanne) 11:599255. https://doi.org/10.3389/fendo.2020.599255

74. Hu W, Lv X, Li C, Xu Y, Qi Y, Zhang Z, Li M, Cai F, Liu D, Yue J, Ye M, Chen Q, Shi K (2020) Disorders of sodium balance and its clinical implications in COVID-19 patients: a multicenter retrospective study. Intern Emerg Med. https://doi.org/10.1007/ s11739-020-02515-9

75. Tzoulis P, Waung JA, Bagkeris E, Hussein Z, Biddanda A, Cousins J, Dewsnip A, Falayi K, McCaughran W, Mullins C, Naeem A, Nwokolo M, Quah H, Bitat S, Deyab E, Ponnampalam S, Bouloux PM, Montgomery H, Baldeweg SE (2021) Dysnatremia is a predictor for morbidity and mortality in hospitalized patients with COVID-19. J Clin Endocrinol Metab. https://doi.org/10. 1210/clinem/dgab107

76. Kleybolte J, Storek B, Hegner B (2021) SARS-CoV-2-induced SIADH: a novel cause of hyponatremia. Z Gerontol Geriatr. https://doi.org/10.1007/s00391-021-01863-1

77. Behl T, Kaur I, Bungau S, Kumar A, Uddin MS, Kumar C, Pal G, Sahil, Shrivastava K, Zengin G, Arora S (2020) The dual impact of ACE2 in COVID-19 and ironical actions in geriatrics and pediatrics with possible therapeutic solutions. Life Sci 257:118075. https://doi.org/10.1016/j.lfs.2020.118075

78. Cuesta M, Thompson CJ (2016) The syndrome of inappropriate antidiuresis (SIAD). Best Pract Res Clin Endocrinol Metab 30(2):175-187. https://doi.org/10.1016/j.beem.2016.02.009

79. Giustina A (2021) Hypovitaminosis D and the endocrine phenotype of COVID-19. Endocrine. https://doi.org/10.1007/ s12020-021-02671-8

80. Yousaf Z, Al-Shokri SD, Al-Soub H, Mohamed MFH (2020) COVID-19-associated SIADH: a clue in the times of pandemic! Am J Physiol Endocrinol Metab 318(6):E882-E885. https://doi. org/10.1152/ajpendo.00178.2020

81. Uddin Chowdhury MR, Akter KS, Moula MM, Kabir MA, Bhuiyan SI, Das BC (2020) COVID-19 presented with syndrome of inappropriate $\mathrm{ADH}$ secretion(SIADH): a case report from Bangladesh. Respir Med Case Rep 31:101290. https://doi.org/ 10.1016/j.rmcr.2020.101290

82. Ho KS, Narasimhan B, Kumar A, Flynn E, Salonia J, El-Hachem K, Mathew JP (2020) Syndrome of inappropriate antidiuretic hormone as the initial presentation of COVID-19: a novel case report. Nefrologia. https://doi.org/10.1016/j.nefro.2020.05.004

83. Ravioli S, Niebuhr N, Ruchti C, Pluess E, Stoeckli T, Lindner G (2020) The syndrome of inappropriate antidiuresis in COVID-19 pneumonia: report of two cases. Clin Kidney J 13(3):461-462. https://doi.org/10.1093/ckj/sfaa080

84. Sheikh MM, Ahmad E, Jeelani HM, Riaz A, Muneeb A (2020) COVID-19 pneumonia: an emerging cause of syndrome of inappropriate antidiuretic hormone. Cureus 12(6):e8841. https://doi. org/10.7759/cureus. 8841

85. Hodax JK, Bialo SR, Yalcindag A (2018) SIADH in systemic JIA resolving after treatment with an IL-6 inhibitor. Pediatrics. https://doi.org/10.1542/peds.2016-4174

86. Khalangot M (2020) COVID-19 and SIADH relations: impact of the positive pressure ventilation. Am J Physiol Endocrinol Metab 319(1):E196. https://doi.org/10.1152/ajpendo.00288.2020

87. De Carvalho H, Letellier T, Karakachoff M, Desvaux G, Caillon H, Papuchon E, Bentoumi-Loaec M, Benaouicha N, Canet E, Chapelet G, Le Turnier P, Montassier E, Rouhani A, Goffinet $\mathrm{N}$, Figueres L (2020) Hyponatremia is associated with poor outcome in COVID-19. Res Square. https://doi.org/10.21203/rs.3. rs-62360/v1

88. Atila C, Sailer CO, Bassetti S, Tschudin-Sutter S, Bingisser R, Siegemund M, Osswald S, Rentsch K, Rueegg M, Schaerli S, Kuster GM, Twerenbold R, Christ-Crain M (2021) Prevalence and outcome of dysnatremia in patients with COVID-19 
compared to controls. Eur J Endocrinol 184(3):413-422. https:// doi.org/10.1530/EJE-20-1374

89. Fernandez Martinez A, Barajas Galindo D, Ruiz Sanchez J (2021) Management of hyponatraemia and hypernatraemia during the Covid-19 pandemic: a consensus statement of the Spanish Society for Endocrinology (Acqua Neuroendocrinology Group). Rev Endocr Metab Disord. https://doi.org/10.1007/ s11154-021-09627-3

90. Chiloiro S, Capoluongo ED, Tartaglione T, Giampietro A, Bianchi A, Giustina A, Pontecorvi A, De Marinis L (2019) The changing clinical spectrum of hypophysitis. Trends Endocrinol Metab 30(9):590-602. https://doi.org/10.1016/j.tem.2019.06.004

91. Muller I, Cannavaro D, Dazzi D, Covelli D, Mantovani G, Muscatello A, Ferrante E, Orsi E, Resi V, Longari V, Cuzzocrea M, Bandera A, Lazzaroni E, Dolci A, Ceriotti F, Re TE, Gori A, Arosio M, Salvi M (2020) SARS-CoV-2-related atypical thyroiditis. Lancet Diabetes Endocrinol 8(9):739-741. https://doi. org/10.1016/S2213-8587(20)30266-7

92. Wei L, Sun S, Zhang J, Zhu H, Xu Y, Ma Q, McNutt MA, Korteweg C, Gu J (2010) Endocrine cells of the adenohypophysis in severe acute respiratory syndrome (SARS). Biochem Cell Biol 88(4):723-730. https://doi.org/10.1139/O10-022

93. Elia G, Ferrari SM, Galdiero MR, Ragusa F, Paparo SR, Ruffilli I, Varricchi G, Fallahi P, Antonelli A (2020) New insight in endocrine-related adverse events associated to immune checkpoint blockade. Best Pract Res Clin Endocrinol Metab 34(1):101370. https://doi.org/10.1016/j.beem.2019.101370

94. Formenti AM, Pedone E, di Filippo L, Ulivieri FM, Giustina A (2020) Are women with osteoporosis treated with denosumab at risk of severe COVID-19? Endocrine 70(2):203-205. https://doi. org/10.1007/s12020-020-02500-4

95. de Joode K, Oostvogels AAM, GeurtsvanKessel CH, de Vries RD, Mathijssen RHJ, Debets R, van der Veldt AAM (2021) Case Report: Adequate T and B Cell responses in a SARS-CoV-2 infected patient after immune checkpoint inhibition. Front Immunol 12:627186. https://doi.org/10.3389/fimmu.2021.627186

96. Colao A, Grasso LFS, Giustina A, Melmed S, Chanson P, Pereira AM, Pivonello R (2019) Acromegaly. Nat Rev Dis Primers 5(1):20. https://doi.org/10.1038/s41572-019-0071-6

97. Melmed S (2020) Pituitary-tumor endocrinopathies. N Engl J Med 382(10):937-950. https://doi.org/10.1056/NEJMra1810772

98. Giustina A (2016) [Acromegaly: reducing diagnostic delay]. Recenti Prog Med 107(8):450-451. https://doi.org/10.1701/2332. 25074

99. Casanueva FF, Barkan AL, Buchfelder M, Klibanski A, Laws ER, Loeffler JS, Melmed S, Mortini P, Wass J, Giustina A, Pituitary Society EGoPT (2017) Criteria for the definition of Pituitary Tumor Centers of Excellence (PTCOE): a Pituitary Society Statement. Pituitary 20(5):489-498. https://doi.org/10.1007/ s11102-017-0838-2

100. Chudasama YV, Gillies CL, Zaccardi F, Coles B, Davies MJ, Seidu S, Khunti K (2020) Impact of COVID-19 on routine care for chronic diseases: a global survey of views from healthcare professionals. Diabetes Metab Syndr 14(5):965-967. https://doi. org/10.1016/j.dsx.2020.06.042

101. Giustina A, Chanson P, Kleinberg D, Bronstein MD, Clemmons DR, Klibanski A, van der Lely AJ, Strasburger CJ, Lamberts SW, Ho KK, Casanueva FF, Melmed S, Acromegaly Consensus G (2014) Expert consensus document: a consensus on the medical treatment of acromegaly. Nat Rev Endocrinol 10(4):243-248. https://doi.org/10.1038/nrendo.2014.21

102. Giustina A, Bronstein MD, Chanson P, Petersenn S, Casanueva FF, Sert C, Houchard A, Melmed S (2019) Staging and managing patients with acromegaly in clinical practice: baseline data from the SAGIT(R) validation study. Pituitary 22(5):476-487. https:// doi.org/10.1007/s11102-019-00977-5
103. Melmed S, Bronstein MD, Chanson P, Klibanski A, Casanueva FF, Wass JAH, Strasburger CJ, Luger A, Clemmons DR, Giustina A (2018) A Consensus Statement on acromegaly therapeutic outcomes. Nat Rev Endocrinol 14(9):552-561. https://doi.org/10. 1038/s41574-018-0058-5

104. Mazziotti G, Giustina A (2010) Effects of lanreotide SR and Autogel on tumor mass in patients with acromegaly: a systematic review. Pituitary 13(1):60-67. https://doi.org/10.1007/ s11102-009-0169-z

105. Samson SL, Nachtigall LB, Fleseriu M, Gordon MB, Bolanowski M, Labadzhyan A, Ur E, Molitch M, Ludlam WH, Patou G, Haviv A, Biermasz N, Giustina A, Trainer PJ, Strasburger CJ, Kennedy L, Melmed S (2020) Maintenance of Acromegaly control in patients switching from injectable somatostatin receptor ligands to oral octreotideAcromegaly control in patients switching from injectable somatostatin receptor ligands to oral octreotide. J Clin Endocrinol Metab. https://doi.org/10.1210/clinem/ dgaa526

106. Maison P, Tropeano AI, Macquin-Mavier I, Giustina A, Chanson $P$ (2007) Impact of somatostatin analogs on the heart in acromegaly: a metaanalysis. J Clin Endocrinol Metab 92(5):1743-1747. https://doi.org/10.1210/jc.2006-2547

107. Durcan E, Turan S, Sahin S, Sulu C, Taze SS, Kavla Y, Ozkaya HM, Kadioglu P (2021) Psychosocial effects and clinic reflections of the COVID-19 outbreak in patients with acromegaly and Cushing's disease. Pituitary. https://doi.org/10.1007/ s11102-021-01136-5

108. Arnaldi G, Angeli A, Atkinson AB, Bertagna X, Cavagnini F, Chrousos GP, Fava GA, Findling JW, Gaillard RC, Grossman AB, Kola B, Lacroix A, Mancini T, Mantero F, Newell-Price J, Nieman LK, Sonino N, Vance ML, Giustina A, Boscaro M (2003) Diagnosis and complications of Cushing's syndrome: a consensus statement. J Clin Endocrinol Metab 88(12):55935602. https://doi.org/10.1210/jc.2003-030871

109. Tatsi C, Boden R, Sinaii N, Keil M, Lyssikatos C, Belyavskaya E, Rosenzweig SD, Stratakis CA, Lodish MB (2018) Decreased lymphocytes and increased risk for infection are common in endogenous pediatric Cushing syndrome. Pediatr Res 83(2):431-437. https://doi.org/10.1038/pr.2017.278

110. Yang M, Chen J, Wei W (2020) Dimerization of glucocorticoid receptors and its role in inflammation and immune responses. Pharmacol Res. https://doi.org/10.1016/j.phrs.2020.105334

111. Bruno NE, Nwachukwu JC, Srinivasan S, Nettles CC, Izard T, Jin Z, Nowak J, Cameron MD, Boregowda SV, Phinney DG, Elemento O, Liu X, Ortlund EA, Houtman R, Stavreva DA, Hager GL, Kamenecka TM, Kojetin DJ, Nettles KW (2021) Chemical systems biology reveals mechanisms of glucocorticoid receptor signaling. Nat Chem Biol 17(3):307-316. https:// doi.org/10.1038/s41589-020-00719-w

112. Hasenmajer V, Sbardella E, Sciarra F, Minnetti M, Isidori AM, Venneri MA (2020) The Immune System in Cushing's Syndrome. Trends Endocrinol Metab 31(9):655-669. https://doi. org/10.1016/j.tem.2020.04.004

113. Zilio M, Mazzai L, Sartori MT, Barbot M, Ceccato F, Daidone V, Casonato A, Saggiorato G, Noventa F, Trementino L, Prandoni P, Boscaro M, Arnaldi G, Scaroni C (2016) A venous thromboembolism risk assessment model for patients with Cushing's syndrome. Endocrine 52(2):322-332. https:// doi.org/10.1007/s12020-015-0665-z

114. Mebrahtu TF, Morgan AW, Keeley A, Baxter PD, Stewart PM, Pujades-Rodriguez M (2019) Dose dependency of iatrogenic glucocorticoid excess and adrenal insufficiency and mortality: a cohort study in England. J Clin Endocrinol Metab. https:// doi.org/10.1210/jc.2019-00153

115. Newell-Price J, Nieman LK, Reincke M, Tabarin A (2020) ENDOCRINOLOGY IN THE TIME OF COVID-19: 
management of Cushing's syndrome. Eur J Endocrinol 183(1):G1-G7. https://doi.org/10.1530/EJE-20-0352

116. Mancini T, Porcelli T, Giustina A (2010) Treatment of Cushing disease: overview and recent findings. Ther Clin Risk Manag 6:505-516. https://doi.org/10.2147/TCRM.S12952

117. Beretta F, Dassie F, Parolin M, Boscari F, Barbot M, Busetto L, Mioni R, De Carlo E, Scaroni C, Fallo F, Vettor R, Maffei P (2020) Practical considerations for the management of Cushing's Disease and COVID-19: a case report. Front Endocrinol (Lausanne) 11:554. https://doi.org/10.3389/fendo.2020.00554

118. Yuno A, Kenmotsu Y, Takahashi Y, Nomoto H, Kameda H, Cho KY, Nakamura A, Yamashita Y, Nakamura J, Nakakubo S, Kamada K, Suzuki M, Sugino H, Inoshita N, Konno S, Miyoshi H, Atsumi T, Sawamura Y, Shimatsu A (2020) Successful management of a patient with active Cushing's disease complicated with coronavirus disease 2019 (COVID-19) pneumonia. Endocr J. https://doi.org/10.1507/endocrj.EJ20-0613

119. Serban AL, Ferrante E, Carosi G, Indirli R, Arosio M, Mantovani G (2020) COVID-19 in Cushing disease: experience of a single tertiary centre in Lombardy. J Endocrinol Invest. https:// doi.org/10.1007/s40618-020-01419-x

120. Belaya Z, Golounina O, Melnichenko G, Tarbaeva N, Pashkova E, Gorokhov M, Kalashnikov V, Dzeranova L, Fadeev V, Volchkov P, Dedov I (2021) Clinical course and outcome of patients with ACTH-dependent Cushing's syndrome infected with novel coronavirus disease-19 (COVID-19): case presentations. Endocrine. https://doi.org/10.1007/s12020-021-02674-5

121. Quinkler M, Ekman B, Zhang P, Isidori AM, Murray RD, Investigators E-A (2018) Mortality data from the European Adrenal Insufficiency Registry-Patient characterization and associations. Clin Endocrinol (Oxf) 89(1):30-35. https://doi. org/10.1111/cen.13609

122. Stewart PM, Biller BM, Marelli C, Gunnarsson C, Ryan MP, Johannsson G (2016) Exploring inpatient hospitalizations and morbidity in patients with adrenal insufficiency. J Clin Endocrinol Metab 101(12):4843-4850. https://doi.org/10.1210/jc. 2016-2221

123. Ebrahimi F, Widmer A, Wagner U, Mueller B, Schuetz P, ChristCrain M, Kutz A (2019) Association of adrenal insufficiency with patient-oriented health-care outcomes in adult medical inpatients. Eur J Endocrinol 181(6):701-709. https://doi.org/10.1530/ EJE-19-0469

124. Bancos I, Hazeldine J, Chortis V, Hampson P, Taylor AE, Lord JM, Arlt W (2017) Primary adrenal insufficiency is associated with impaired natural killer cell function: a potential link to increased mortality. Eur J Endocrinol 176(4):471-480. https:// doi.org/10.1530/EJE-16-0969

125. Tresoldi AS, Sumilo D, Perrins M, Toulis KA, Prete A, Reddy N, Wass JAH, Arlt W, Nirantharakumar K (2020) Increased infection risk in Addison's disease and congenital adrenal hyperplasia. J Clin Endocrinol Metab. https://doi.org/10.1210/clinem/dgz006

126. Iwasaku M, Tanaka S, Shinzawa M, Kawakami K (2019) Impact of underlying chronic adrenal insufficiency on clinical course of hospitalized patients with adrenal crisis: a nationwide cohort study. Eur J Intern Med 64:24-28. https://doi.org/10.1016/j.ejim. 2019.04.001

127. Mazziotti G, Formenti AM, Frara S, Roca E, Mortini P, Berruti A, Giustina A (2017) MANAGEMENT OF ENDOCRINE DISEASE: Risk of overtreatment in patients with adrenal insufficiency: current and emerging aspects. Eur J Endocrinol 177(5):R231-R248. https://doi.org/10.1530/EJE-17-0154

128. Carosi G, Morelli V, Del Sindaco G, Serban AL, Cremaschi A, Frigerio S, Rodari G, Profka E, Indirli R, Mungari R, Resi V, Orsi E, Ferrante E, Dolci A, Giavoli C, Arosio M, Mantovani G (2020) Adrenal insufficiency at the time of COVID-19: a retrospective study in patients referring to a tertiary centre. $\mathbf{J}$ Clin Endocrinol Metab. https://doi.org/10.1210/clinem/dgaa793

129. Loli P, Frara S, Pasquali R, Di Filippo L, Rovere-Querini P, Giustina A (2020) COVID-19 and hypopituitarism. Experience from an endocrine center in a high-impact area. Endocrine Abstract 70:AEP1075. https://doi.org/10.1530/endoabs.70.AEP1075

130. Ko JJ, Wu C, Mehta N, Wald-Dickler N, Yang W, Qiao R (2021) A comparison of methylprednisolone and dexamethasone in intensive care patients with COVID-19. J Intensive Care Med. https://doi.org/10.1177/0885066621994057

131. Zhang Y, Hu S, Wang J, Xue Z, Wang C, Wang N (2021) Dexamethasone inhibits SARS-CoV-2 spike pseudotyped virus viropexis by binding to ACE2. Virology 554:83-88. https://doi. org/10.1016/j.virol.2020.12.001

132. Leow MK, Kwek DS, Ng AW, Ong KC, Kaw GJ, Lee LS (2005) Hypocortisolism in survivors of severe acute respiratory syndrome (SARS). Clin Endocrinol (Oxf) 63(2):197-202. https:// doi.org/10.1111/j.1365-2265.2005.02325.x

133. Rouanet I, Peyriere H, Mauboussin JM, Vincent D (2003) Cushing's syndrome in a patient treated by ritonavir/lopinavir and inhaled fluticasone. HIV Med 4(2):149-150. https://doi.org/10. 1046/j.1468-1293.2003.00149.x

134. Fleseriu M, Buchfelder M, Cetas JS, Fazeli PK, Mallea-Gil SM, Gurnell M, McCormack A, Pineyro MM, Syro LV, Tritos NA, Marcus HJ (2020) Pituitary society guidance: pituitary disease management and patient care recommendations during the COVID-19 pandemic - an international perspective. Pituitary 23(4):327-337. https://doi.org/10.1007/s11102-020-01059-7

135. Kolias A, Tysome J, Donnelly N, Sharma R, Gkrania-Klotsas E, Budohoski K, Karcheva S, Adapa R, Lawes I, Gurnell M, Hutchinson P, Bance M, Axon P, Santarius T, Mannion RJ (2020) A safe approach to surgery for pituitary and skull base lesions during the COVID-19 pandemic. Acta Neurochir (Wien) 162(7):1509-1511. https://doi.org/10.1007/s00701-020-04396-5

136. Iorio-Morin C, Hodaie M, Sarica C, Dea N, Westwick HJ, Christie SD, McDonald PJ, Labidi M, Farmer JP, Brisebois S, D'Aragon F, Carignan A, Fortin D (2020) Letter: The risk of COVID-19 infection during neurosurgical procedures: a review of severe acute respiratory distress syndrome coronavirus 2 (SARS-CoV-2) modes of transmission and proposed neurosurgery-specific measures for mitigation. Neurosurgery 87(2):E178E185. https://doi.org/10.1093/neuros/nyaa157

137. Zou L, Ruan F, Huang M, Liang L, Huang H, Hong Z, Yu J, Kang M, Song Y, Xia J, Guo Q, Song T, He J, Yen HL, Peiris M, Wu J (2020) SARS-CoV-2 viral load in upper respiratory specimens of infected patients. N Engl J Med 382(12):1177-1179. https:// doi.org/10.1056/NEJMc2001737

138. Yuen KCJ, Blevins LS Jr, Findling JW (2020) Important management considerations in patients with pituitary disorders during the time of the Covid-19 pandemic. Endocr Pract 26(8):915-922. https://doi.org/10.4158/EP-2020-0308

139. Ho KKY, Fleseriu M, Wass J, van der Lely A, Barkan A, Giustina A, Casanueva FF, Heaney AP, Biermasz N, Strasburger C, Melmed S (2019) A tale of pituitary adenomas: to NET or not to NET: Pituitary Society position statement. Pituitary 22(6):569573. https://doi.org/10.1007/s11102-019-00988-2

140. Mitchell RA, King JAJ, Goldschlager T, Wang YY (2020) Impact of COVID-19 on pituitary surgery. ANZ J Surg 90(6):963-964. https://doi.org/10.1111/ans.15959

141. Fleseriu M, Dekkers OM, Karavitaki N (2020) Endocrinology in the time of COVID-19: management of pituitary tumours. Eur J Endocrinol 183(1):G17-G23. https://doi.org/10.1530/ EJE-20-0473

142. Akai T, Maruyama K, Takakura H, Yamamoto Y, Morinaga Y, Kuroda S (2020) Safety management in urgent endonasal transsphenoidal surgery for pituitary adenoma during the COVID-19 
pandemic in Japan-a case report. Interdiscip Neurosurg 22:100820. https://doi.org/10.1016/j.inat.2020.100820

143. Ai T, Yang Z, Hou H, Zhan C, Chen C, Lv W, Tao Q, Sun Z, Xia L (2020) Correlation of chest CT and RT-PCR testing for coronavirus disease 2019 (COVID-19) in China: a report of 1014 cases. Radiology 296(2):E32-E40. https://doi.org/10.1148/radiol.20202 00642

144. Tilmans G, Chenevas-Paule Q, Muller X, Breton A, Mohkam K, Ducerf C, Mabrut JY, Lesurtel M (2020) Surgical outcomes after systematic preoperative severe acute respiratory syndrome coronavirus 2 (SARS-CoV-2) screening. Surgery 168(2):209-211. https://doi.org/10.1016/j.surg.2020.05.006

145. Penner F, Grottoli S, Lanotte MMR, Garbossa D, Zenga F (2021) Pituitary surgery during Covid-19: a first hand experience and evaluation. J Endocrinol Invest 44(3):635-636. https://doi.org/ 10.1007/s40618-020-01354-x

146. Polack FP, Thomas SJ, Kitchin N, Absalon J, Gurtman A, Lockhart S, Perez JL, Perez Marc G, Moreira ED, Zerbini C, Bailey R, Swanson KA, Roychoudhury S, Koury K, Li P, Kalina WV, Cooper D, Frenck RW Jr, Hammitt LL, Tureci O, Nell H, Schaefer A, Unal S, Tresnan DB, Mather S, Dormitzer PR, Sahin U, Jansen KU, Gruber WC, Group CCT (2020) Safety and efficacy of the BNT162b2 mRNA Covid-19 vaccine. N Engl J Med 383(27):2603-2615. https://doi.org/10.1056/NEJMoa2034577

147. Baden LR, El Sahly HM, Essink B, Kotloff K, Frey S, Novak R, Diemert D, Spector SA, Rouphael N, Creech CB, McGettigan
J, Khetan S, Segall N, Solis J, Brosz A, Fierro C, Schwartz H, Neuzil K, Corey L, Gilbert P, Janes H, Follmann D, Marovich M, Mascola J, Polakowski L, Ledgerwood J, Graham BS, Bennett H, Pajon R, Knightly C, Leav B, Deng W, Zhou H, Han S, Ivarsson M, Miller J, Zaks T, Group CS (2021) Efficacy and safety of the mRNA-1273 SARS-CoV-2 vaccine. N Engl J Med 384(5):403-416. https://doi.org/10.1056/NEJMoa2035389

148. Grossman AB (2010) Clinical Review\#: the diagnosis and management of central hypoadrenalism. J Clin Endocrinol Metab 95(11):4855-4863. https://doi.org/10.1210/jc.2010-0982

149. Katznelson L, Gadelha M (2021) Glucocorticoid use in patients with adrenal insufficiency following administration of the COVID-19 vaccine: a pituitary society statement. Pituitary. https://doi.org/10.1007/s11102-021-01130-x

150. Sokolowska M, Eiwegger T, Ollert M, Torres MJ, Barber D, Del Giacco S, Jutel M, Nadeau KC, Palomares O, Rabin RL, Riggioni C, Vieths S, Agache I, Shamji MH (2021) EAACI statement on the diagnosis, management and prevention of severe allergic reactions to COVID-19 vaccines. Allergy. https://doi. org/10.1111/all.14739

Publisher's note Springer Nature remains neutral with regard to jurisdictional claims in published maps and institutional affiliations. 